\title{
Observation of Intra ocular Pressure in Normal Eyes of Population Surrounding Bhagalpur District of Bihar
}

\author{
${ }^{1}$ Dr. Uma Shankar Singh, ${ }^{2}$ Dr. Pummy Roy, ${ }^{3}$ Dr. Pankaj Kumar \\ AssosiateProfessor, Eye department, Jawaharlal Nehru medical college \&Hospital, Bhagalpur \\ Senor Resident, Eye department, Jawaharlal Nehru medical college \&Hospital, Bhagalpur \\ AssitantProfessor,Neurosurgery, Jawaharlal Nehru medical college \&Hospital, Bhagalpur
}

\section{Introduction}

In order that the eye may satisfactorily perform its duties as an organ of vision, it is essential that the media should be optically transparent and that sharp image of object of outer world be formed upon the retina. For these purpose the cornea and the lens must be avascular and transparent and the fluid filling the globe be optically clear and at the same time remain under sufficient pressure to keep the walls of the globe taut and the optical surface in proper position. To attain these purposes, physiology of the eye differs in many respects from that of other organs. The main problem being concerned with the nature and formation of the intraocular fluid and the maintenance of intraocular pressure(IOP).To maintain of intraocular pressure(IOP) depends upon two factors (i)Formation of intraocular fluid(II)The resistance of its outflow

The first factor is a combination of ultrafiltration of fluid from intraocular capillaries due to hydrostatic pressure and transfer of fluid into posterior chamber by osmotic pressure following active transportation of sodium ion by the metabolic activity of the cells of cilliary capillaries. The second factor is largely the resistance of the exit of this fluid at the angle of anterior chamber offered by drainage channel and this is superadded by the pressure inside the episcleral vein which also forms a part of drainage system, these two factors maintain an equilibrium between them, so the IOP is maintained at a level. Apart from these there are some other factors i.eincrease in external pressure over the eyeball or alteration in the volume of the content of eyeball, which may lead mild to acute alternation in IOP but usually temporary in nature, thus it is obvious that two types of changes in IOP may occur.

(I) Changes which vary according to the equilibrium between the factors responsible for formation of intraocular fluid and the resistance to its out flow, if any factor is altered without a corresponding and compensating changes in other factors a new IOP will result but this cannot be of a steady nature. The steady stage can only be established when the aquoushumour formation is equal to the rate of its drainage .

(II) Changes which is transient in nature is depending upon the alternation in external forces being exterted over the globe or volumetric changes within it. When these changes occur for a period the rate of aquoushumour formation differs from the rate of its drainage. These changes are effective only for a limited time and as soon as the causes of these changes is removed the pressure returns to its steady level.

The normal IOP is statistical average IOP measured in millimeter of mercury . It is $15.4 \mathrm{~mm}$ with standarded deviation of $\pm 2.5 \mathrm{~mm}$ for applanation tonometer in sitting position and $16.1 \mathrm{~mm}$ with standared deviation of $\pm 2.8 \mathrm{mmwithschiotz}$ tonometer in supine position. The normal range is $10-21 \mathrm{~mm}$. Statistically it is over $21 \mathrm{~mm}$ in $2.5 \%$ of normal and over $24 \mathrm{~mm}$ in $0.15 \%$.

\section{Material And Method}

For the present work 1200 healthy eyes of 600 patients were examined, among 600 patients 380 patients were male and 220 patients were female. The examination were conducted in eye out patient department of Jawaharlal Nehru medical college hospital Bhagalpur and private clinics of concerned colleagues. In the hospital and clinics only those patients were examined who were attendingrefraction section and only those cases were included in this series whose vision was $6 / 6$ or 6/9 in both eyes with or without glasses. After preliminary examination of vision the selected patient were subjected to detailed examination which included general clinical as well as local examination of the eyes. In local examination apart from vision anterior segment and fundus both were examined properly for any abnormality the patient with any changes in the fundus or any other evidence of any ophthalmic diseases was dropped from these series. Besides these history of any pastmajor ophthalmic diseases onintrogation was also taken as disqualification, all these findings were recorded in the case sheet . 


\section{Observation}

Twelve hundered eyes in six hundred patient were examined and included in these series. The results were tabulated according to age and sex groups and analysedstatiscally. All cases where pressure was recorded $21 \mathrm{~mm} \mathrm{Hg}$ were subjected to ophthalmoscopic, perimetric and provocative tests for detection of glaucoma. No subjective and objective evidence could be found to establish the diagnosis of glaucoma in these cases. IOP was measured by schiotz tonometer as mentioned earlier and the readings in different ranges varying from less than $10 \mathrm{~mm} \mathrm{Hg}$ to more than $21 \mathrm{~mm} \mathrm{Hg}$ these have been tabulated and percentage of eyes showing different range variation have been found out as showing in table as below

Table no. 1showing number and percentage of eyes with different range variation in IOP

\begin{tabular}{|c|l|c|c|}
\hline No. & \multicolumn{1}{|c|}{ Range variation } & No. of eyes & percentage \\
\hline 1. & Less than $10 \mathrm{~mm} \mathrm{Hg}$ & 02 & 0.17 \\
\hline 2. & 10 to $14 \mathrm{~mm} \mathrm{Hg}$ & 304 & 25.33 \\
\hline 3. & 14.1 to $18 \mathrm{~mm} \mathrm{Hg}$ & 620 & 51.66 \\
\hline 4. & 18.1 to $20 \mathrm{~mm} \mathrm{Hg}$ & 250 & 20.84 \\
\hline 5. & Above $21 \mathrm{~mm} \mathrm{Hg}$ & 24 & 2.00 \\
\hline & Total & 1200 & 100.00 \\
\hline
\end{tabular}

It is evident from this table that the maximum number of eyes $51.66 \%$ have been found in the IOP range group of 14.1 to $18 \mathrm{~mm} \mathrm{Hg}$ and minimum no. of eyes $0.17 \%$ have been found in the IOP range group less than $10 \mathrm{~mm} \mathrm{Hg}$.

Table no. $\mathbf{- 2}$ showing normal IOP distribution according to age group

\begin{tabular}{|c|c|c|c|c|c|c|c|}
\hline No. & Age group & $\begin{array}{l}\text { No. of eyes } \\
<10 \mathrm{~mm} \mathrm{Hg}\end{array}$ & $\begin{array}{c}\text { No. of eyes } \\
10-14 \mathrm{~mm} \\
\mathrm{Hg} \\
\end{array}$ & $\begin{array}{c}\text { No. of eyes } \\
14.1-18 \mathrm{~mm} \\
\mathrm{Hg}\end{array}$ & $\begin{array}{c}\text { No. of eyes } \\
18.1 \mathrm{-21} \mathrm{mm} \\
\mathrm{Hg} \\
\end{array}$ & $\begin{array}{c}\text { No. of eyes } \\
>21 \mathrm{~mm} \\
\mathrm{Hg}\end{array}$ & total \\
\hline 1. & $<20$ years & 2 & 38 & 196 & 106 & 12 & 354 \\
\hline 2. & $21-40$ years & 0 & 140 & 276 & 130 & 4 & 550 \\
\hline 3. & $41-60$ years & 0 & 63 & 78 & 8 & 7 & 156 \\
\hline 4. & $>60$ years & 0 & 63 & 70 & 6 & 1 & 140 \\
\hline & Total & 2 & 304 & 620 & 250 & 24 & 1200 \\
\hline
\end{tabular}

According to rable no 2 it is evident that the maximum no of eyes 550 (45.83\%) have been found in the age group of 21-40 years age and minimum no. of eyes have been found in the age group of above 60 years of age i.e $140(11.66 \%)$

Table no. -3 showing no and percentage having different ranges of IOP along with the presumed normal average variation

\begin{tabular}{|l|l|l|l|l|l|l|}
\hline \multirow{2}{*}{ No. } & \multirow{2}{*}{ Range of IOP } & \multicolumn{4}{|c|}{ Age group and numbers } & $\begin{array}{l}\text { Presumed normal } \\
\text { average }\end{array}$ \\
\cline { 3 - 6 } & & $\begin{array}{l}\text { No. of eyes } \\
\text { <2 years }\end{array}$ & $\begin{array}{l}\text { No. of eyes } \\
\mathbf{2 1 - \quad 4 0} \\
\text { years }\end{array}$ & $\begin{array}{l}\text { No. of eyes } \\
\mathbf{4 1 - 6 0} \\
\text { years }\end{array}$ & $\begin{array}{l}\text { No. of eyes } \\
\text { 60 years }\end{array}$ & \\
\hline 1. & $<10 \mathrm{~mm} \mathrm{Hg}$ & 02 & 0 & 0 & 0 & $2(0.17 \%)$ \\
\hline 2. & $10-14 \mathrm{~mm} \mathrm{Hg}$ & 76 & 104 & 108 & 16 & $304(25.33 \%)$ \\
\hline 3. & $14.1-18 \mathrm{~mm} \mathrm{Hg}$ & 280 & 238 & 95 & 07 & $620(51.66 \%)$ \\
\hline 4. & $18.1-21 \mathrm{~mm} \mathrm{Hg}$ & 68 & 74 & 102 & 06 & $250(20.83 \%)$ \\
\hline 5. & $>21 \mathrm{~mm} \mathrm{Hg}$ & 06 & 06 & 03 & 09 & $24(2 \%)$ \\
\hline & total & 432 & 422 & 308 & 38 & $1200(100 \%)$ \\
\hline
\end{tabular}

According to table no.- 3 ,It is evident from table no. -3 that the maximum no. of eyes i.e $620(51.66 \%)$ having IOP range in between 14.1 to $18 \mathrm{~mm} \mathrm{Hg}$ and minimum no. of eyes i.e 2(0.17\%) have IOP <10 mm $\mathrm{Hg}$ range group. Further among 14.1 to $18 \mathrm{~mm} \mathrm{Hg}$ IOP range the maximum no. of eyes are in the age group having $<20$ years of age i.e $280(23.33 \%)$ and minimum no. of eyes i.e 07(0.58\%) having more than 60 years of age.It is also evident from this table that the no. of eyes are nil( $0 \%$ ) having less than $10 \mathrm{~mm} \mathrm{Hg}$ above 20 years of age.

\section{Discussion And Conclusion}

The normal range of IOP is very wide which usually varies between 10 to $24 \mathrm{mmHg}$ schiotz but the value towards the high end of this range may be physiological or pathological. Therefore it is very essential to know the safe range of IOP which may serve as a guideline for ophthalmologist while diagnosing or treating a case of glaucoma. As already stated it is very difficult to find the highest value of IOP which may be harmless to eye but some workers have purposed an upper limit of IOP, according to Wegner (1911) Andrezen(1920) and Muller(1931) a tension above $28 \mathrm{~mm} \mathrm{Hg}$ excites a suspicion of glaucoma and tension above $35 \mathrm{~mm} \mathrm{Hg}$ is definitely pathological, since the normal maximum IOP is known to be as high as $35 \mathrm{~mm} \mathrm{Hg}$. While estimating 
the IOP with tonometer any error of measurement also alters the apparent range variation of IOP in normal eyes. Suppose the probable error in a tonometer reading is \pm one half of a tonometer scale unit this error corresponds to a probable error of \pm three $\mathrm{mm} \mathrm{Hg}$ in the region of normal IOP and thus may change the value of actual IOP.The IOP also varies from person to person of as other biological variation. In this series some abnormal data were observed which may be due to the individual variation in different human being which do not follow strictly the normal frequency distribution pattern other reason for such aberrant data may be the internal defect in the project. Apart from these types of defects there are also other sources of a error present such as while recording IOP with schiotz tonometer recording are made to the nearest whole scale division. The pointer of tonometer oscillates with the pulse and respiration and movement of the patient itself add to this confusion.In these conditions \pm half scale division error is very common. In case of abnormal scleral rigidity the results are far off the exact IOP, so it is quite obvious that schiotz tonometer is not an ideal tonometer but being portable and inexpensive is used very in clinical practice even with its limitation. The findings in this series are similar to those of previous workers but most of them have conducted their work outsideBihar or even India but this work is performed in the population surrounding Bhagalpur district of Bihar which is the working place of workers.

\section{References}

[1]. Allimuddin,m. : British, journal. ophthalmology

[2]. Alder F.H. : Physiology of the eye St. Louis, C.V. Mosby.

[3]. Armaly, M.F. : American. journal.

[4]. Ophthalmology.Becker,B. : Friedenwald J.S.: Arch. Ophthalmology.

Badlini,H.G.\& : Journal all india Ophthalmology

Telan B.D.

[5]. Duke-Elder : Journal Physiology

[6]. Drance, S.M. $\quad$ : Studies in the susceptibility of the eye to

[7]. raised intraocular pressure

[8]. Archs. Ophthalmology

[9]. Duke-Elder,S. : System of Ophthalmology

[10]. Davson, H. : The Eye, New York,Acad.Pressinc

[11]. Eggink,E.D. : Tonometry as a routine in tracing Primary

[12]. glaucoma, Ophthalmological

[13]. Friedenwald,J.S. : Contribution to the theory and practice of tonometry

[14]. Friedenwald : Decennial report by the Committee on the standardization of tonometer, Amer.Acad. Ophthalmology.Cited by Duke-Elder

[15]. Gloster : Tonometry and tonography.Lond. Lawrence and Schlegel. : Invest. Ophthalmology.

[16]. Mc.Bain,Earle,H. : Tonometry,InternalOphthalmology.

[17]. Miller,J.H. : Parsons Diseases of the Eye, Nesterov,A.;Bunin,A., : Intraocular pressure,Physiology and Pathology

[18]. Katsnelson, L

[19]. Parson : Pathology of Eye

[20]. Smith Redmond J.H. : : Clinical glaucoma

[21]. Walker.W.M. : Diagnostic tests for glaucoma.

[22]. Quigley HA. : Number of people with glaucoma

[23]. worldwide. BritishjournalOphthalmology

[24]. Cook C,Foster P. : Epidemiology of Glaucoma

[25]. Wang YX,Xu L, :Prevalence of Glaucoma in NorthChina.TheYang H, Jonas JBBeijing Eye Study. Wen W, Juerti, : The Analysis in proportion in Hospitalized

[26]. AbudukaderPatient with glaucoma. Journal of Xinjiang

[27]. medical university.

[28]. He M,FosterPJ,Ge J,

[29]. Huang W, Zheng Y,

[30]. Friedman DS, et al.

[31]. Doshi V, Ying- Lai

[32]. style risk factorsfor open angle glaucoma
[33]. and ocular hypertension. The Los Angeles

[34]. Latino Eye study

[35]. Zanon-Moreno V, : Smoking and additional risk factorin elder

[36]. Garcia-Medina JJ women with primary open- angel glaucoma

[37]. Zanonj-Viguer V 